Danny Meadows-Klue is Chief Executive, Digital Strategy Consulting.
Keywords: relationship marketing, marketing paradigms, web, digital, strategy

\section{Falling in Love 2.0: Relationship marketing for the Facebook generation}

\author{
Danny Meadows-Klue
}

Received: 29 October 2007

\begin{abstract}
Until now the relationship between brands and consumers has been one way. The rules of marketing had to change, and the web has proved a catalyst in bringing the changes forward and amplifying their scale. The removal of frictions in the spread of information has created a radically different landscape for marketers to work within and this is a key element in understanding how the first generation of internet marketing works. The sudden emergence of the Web 2.0 marketing techniques demand additional approaches, and while most marketers are still wrestling with the first generation, savvy brands are exploring the landscape that social media and social networks create for marketers. These techniques are allowing much deeper drivers in social change to be unleashed, with a profound impact on planning customer connections. The new generation of relationship marketing responds to the additional challenges of digital media literacy, and in the right hands can trigger a rebuild of the entire marketing mix. Relationship marketing for the Facebook generation demands both thinking and acting differently. Journal of Direct, Data and Digital Marketing Practice (2008) 9, 245-250. doi:10.1057/palgrave.dddmp.4350103
\end{abstract}

\section{Introduction}

The rules of the marketing game have changed. The command and control television era, where big brands were built by heavyweight messaging to the nation every night, is drawing to an end. In its place, a radically new structure is emerging that will dominate marketing, recasting the discipline and demanding a new direction in customer communication. For the brands that can persuade their customers to fall in love and join in conversation, the pickings will be rich. For those that fail, no amount of marriage guidance will mend the rift. Internet marketing is simply the catalyst for a sea change that had been long coming. Awareness messaging may still drive TV spend, but social media will play a critical part in driving purchase intent as well as delivering brand engagement in the digital networked society.

\section{Customers evolved; but did marketing?}

Somewhere along the journey of marketing, the skill to listen has weakened and the art of engagement lost in favour of ever grander and 


\section{Growth of brand Marketing}

\section{Explosion of media channels}

\section{Overcoming frictions}

louder messaging techniques, raising the bar for cut-through, but doing little to create true dialogue with the customers. The techniques worked for decades, but while hitting a target audience across ever more channels created a crescendo of voices, its side effects were the creation of an astute form of media literacy, and the potential for marketing scepticism among consumers. The technologies and distribution channels of marketing may have evolved, but day-to-day practices and one-way messaging changed little. Only in direct marketing was there an appreciation of the need for relevance and precision, and through database marketing it could start to be explored.

The growth of brand marketing created a climate of receptiveness for a new formula, and brands that could read the changing emotions and needs among their consumers in this new landscape would enjoy reaping the benefits. From Easyjet and Egg, to Apple and Innocent, from Smart and Dyson, to Google and The Guardian, some brands focused so heavily on their product that they succeeded in a breakthrough in excellence or value that would let the brand's truths drive the messaging. In these cases the consumer's search for authenticity was quenched, and the effect on sales evident. The marketing model of consumer conversations to promote brands was working hard.

\section{The web was only a catalyst}

With or without the web, something was set to change. The expanding volume of marketing messaging has led to customers craving this authenticity, and their sophisticated (and growing) sense of marketing literacy affects the impact of advertising across all channels. The patterns have been similar across the US and Europe.

About the same time, the explosion of media channels was creating the fragmentation migraine media planners will have to wrestle with for another decade. All the world wide web did was simply accelerate an existing trend by placing control in customers' hands or, more accurately, in their mice. Media literacy evolved into digital media literacy, and another step-change took place, this time in an audience's shift to manage and select their own exposure to marketing messages. As time-shifted media consumption and personal media scheduling became the norm, with iTunes and Bittorrent going mainstream, this trend will only amplify.

\section{Removing frictions in the access to knowledge}

Barriers to the spread of information and knowledge are vast. Across every surface there are frictions, and whether the information is about the value of a second-hand car, or the features of a new product, getting the message to spread demands overcoming these frictions. Much of our industry's work is channelled into this, but the web is a near-frictionless media channel along which anything can flow. Google your questions, plug in your RSS feeds, let Amazon show you how 'people who like this also like this', and what you are witnessing is the 
flow of information without friction. 'Paradigm shift' is an overused phrase, but this removal of friction warrants it. That is the surface over which social media is laid and conversations about brands now travel.

\section{Paradigm shifts demand new models}

The first generation of commercial web content replicated on-screen content that was designed for and sourced from classic channels: this was the copy-and-paste era of web production. Whether for marketing or editorial, gradually the norms in the production of content evolved: the copy-paste-improve era. The addition of hyperlinks added referencing, the use of metadata provided greater context, the animation of stories with pictures and then video added richness, and the content management technologies divorced structure from form to create easier manipulation. These are all examples of writing for the medium, but the fundamental communication model is still the one-way model of Caxton's, albeit with enhanced performance 'Caxton-on-steroids'.

\section{Social media and social networks: New landscapes and new paradigms}

After the dotcom crash, a series of success story digital firms started to emerge. Under the microscope, their corporate DNA looked like it might share many of the same genes. These digital natives seemed to have a surprising amount in common and, from around 30 different strands of behaviour, the genes of the second generation of internet communications were isolated. In an industry infamous for its jargon, 'Web 2.0' became the new buzzword, and Facebook, Google, Craigslist, MySpace, Flickr, Wikipedia etc became its icons.

Web 2.0

Within the Web 2.0 DNA, there is the creation of platforms that connect people together (social networks), the ability to produce and then share content with others (social media), the success in architecting frameworks for participation (rather than producing all the content), and extracting and processing some of a community's knowledge and then sharing it back (collective intelligence). There are many more, but these have some of the strongest implications for brands, and represent paradigms of communication unique to the digital networked society. By understanding the genetic code, marketers can learn how to behave in these new spaces.

\section{Digital media literacy}

Cultural evolution has empowered consumers
Cultural evolution, catalysed by technology and typified by the web, has empowered media-savvy consumers with the tools to filter and select in a way never before possible. Customers initially were simply exercising greater control of their media, but doing this within the framework of a learned behaviour: television news would still be watched in the evening (albeit on time-delay thanks to BBC.co.uk), the internet edition of The Daily Telegraph could replace the print title and search engines could replace parts of the business to business press. But many consumers have 


\section{Expectations grow}

\section{Trends}

\section{'Falling in Love 2.0'}

crossed that stepping stone to reappraise their media altogether, exhibiting the behaviour of digital natives rather than immigrants.

In this new environment linear broadcast television may be dropped altogether. An iPod is as likely to carry the television show as a plasma in the living room, newspaper home pages get replaced by the transient flows of an RSS feed reader, and the message platform spills across all devices. The result for advertising? The interruptive model of shouting for attention dies at the rate the number of people prepared to be shouted to dwindles. Make no mistake, media life has evolved.

Along the way, customers have been empowered by the new tools and their expectations have leapt. The transparency of price and service that many first experienced in the pages of PriceRunner and Kelkoo has become embedded in consumer culture. 'Brand' still commands a price premium, but maintaining that brand value and the scale of that premium will be major issues for firms. There is a natural flow of consequences from these changes:

- empowerment creates customers in control of media

- digital channels create time

- time creates communication opportunities

- opportunity creates competitive advantage

- transparency creates accountability.

\section{Consequences of change}

The rise of the web, consumers' increasing digital media literacy and the explosive growth of online social networks have consequences that marketers need to understand if their relationship with consumers is to blossom. Since 2000, at Digital, we have been tracking these developments and translating them into trends marketers can harness:

- engagement replaces interruption

- diversity and self-expression replace conformism and unity

- the media of the masses replace mass media

- granular insights and rich data replaces generalisation

- conversations in marketing replace control.

'Falling in Love 2.0' is about understanding these contexts and appreciating the new rules for successful loving relationships. Only an understanding of why media-savvy consumers tune out of classic media can create the right thinking that permits re-engagement. Only by earning the trust of their friends will brands get recommended by those friends, and only by investing time and energy in listening and building that relationship will there be a loving relationship to enjoy.

The channel selection will still be broad, with many models for integration, but a consistent theme of brands as triggers, participants and enablers of conversation. We are witnessing a watershed in marketing, and while it is certainly 'all change' from the way most brands have behaved in the past, are not the new rules of transparency, equality and conversation simply how we would all like to be treated? 


\section{Marriage guidance}

In this new world, it is no surprise that many brands are failing to engage consumers. Long before the web went mainstream, social analysts were tracking how the trust people place had switched from institutions to their friends, and with that an implication for how marketing should be delivered effectively. Social media and online social networks simply unlocked an existing human need, and accelerated the trend by enabling everyone touched by the web to revel in the new toolkits.

Many marketers appreciated this and began to follow, racing to colonise the new social spaces, but doing it with the models of the past. That is why the tumbleweeds are still rolling through so much of Second Life, and why many of the early attempts at corporate blogging (like Cillit Bang's catastrophic posting strategy) actually harmed the brands they were trying to market.

\section{Real relationships let Love 2.0 blossom}

As blogging and social media moved from the margins to the mainstream, the impact on commerce starts to become clear. Groups on Facebook are changing the behaviour of brands from the challenges faced by HSBC (changing banking terms for students after protests) to the excitement around Cadbury's (bringing back Wispa chocolate bars). Bloggers are holding corporates to account (Supermarket Sweep-Up keeps watchful eyes on Tesco), while some corporates (such as board members of Sun Microsystems, who all blog) are holding up the standards for transparency and authenticity in blogging.

\section{Promotional content}

\section{Divese and intricate techniques}

The entertainment industry is now fuelling social media with promotional content (there are thousands of examples from the Harry Potter launch publicity to the Lord of the Rings' pre-release research). While many brands are creating their own presence within social media, other brands are feeding campaigns into the online social networks (with Coke and PotNoodle among the many food and drink brands to succeed in this new era of viral marketing).

The techniques are also becoming more diverse and more intricate. Dove's 'Campaign For Real Beauty' culminated in the 'Evolution' video that in just over a minute told the story of how artificial a magazine cover girl's image is, and in doing so sparked millions of online conversations as the content flowed frictionlessly across YouTube and the blogoshpere. Similarly Nike's city running platform has brilliantly placed the web at the core of blended, connected marketing strategies that create social spaces as the hub around which a brand's activity - from traditional above the line to PR to events takes place.

From food to pharmaceuticals, many brands are starting to find models for marketing that harness Web 2.0. Invest the time in a strategic framework, and rather than the classic 'one-night-stand' campaign marketing, build relationships that get richer and stronger. 
Journey has just begun

\section{Relationships and relationship marketers}

When brands talk about relationships in marketing, and searching for the 'love' they want customers to share, most do this through the lens of a relationship between parent and infant. But now our infant has grown up, the unconditional belief they once held has evaporated, the context of the rest of the world is clear, they have the confidence to question, and know they can ask their friends.

Direct marketers who understand customer relationships are well placed to be the architects of these strategies and solutions. The belief in relevancy, the ability to listen, the practice of measurement, the constant fine-tuning and optimisation: they are all skills needed to help build strong relationships in the digital space.

If all this feels like a new world order, then the daunting reality is that we are still only a small way along the journey. The sudden explosion of social media since 2005 is the starkest of reminders about how fast the tools of the digital networked society continue to unfold. Barriers to the flow of information have melted away, and yet the consequences have barely been felt. For the brands and marketers that understand the new relationship rules, marketing to the Facebook generation will not be confined to harnessing the digital channels, it will change every way the firm communicates. 